\title{
Integrating The Wall Street Journal Into AIS Courses
}

\author{
James M. Kohlmeyer, III, East Carolina University
}

\begin{abstract}
While it is important for accounting information systems (AIS) students to understand computer technology, internal controls and business processes, such knowledge is of little use without reference to appropriate contexts. Integrating Wall Street Journal (WSJ) readings and discussions into AIS classes can enrich learning by stimulating discussions based on real-life experiences. This article illustrates how the WSJ can be used in AIS courses to reinforce learning in key areas, such as information privacy, data security, identity theft, and business continuity.
\end{abstract}

Keywords: Wall Street Journal, AIS, accounting education

\section{INTRODUCTION}

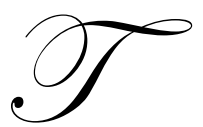

he purpose of this paper is to discuss ways to integrate the Wall Street Journal (WSJ) into accounting information systems (AIS) courses. This paper is motivated by a belief that AIS students should be exposed to a regular dose of real-world contexts to supplement academic concepts presented in relatively sterile classroom settings. Integrating the WSJ into the classroom will help to make accounting courses in general and AIS courses in particular more interesting through the integration of real-life applications.

The emphasis on memorization of rules, principles and procedures throughout the accounting curricula seems to discourage many top-quality students from majoring in accounting. For instance, Adams et al. (1994) found that, based on grades received in the first accounting course, the top $25 \%$ of those who chose not to major in accounting received higher grades in the course than those who majored in accounting. Based on student focus groups, Inman et al. (1989, p.40) summarize many students' views of accounting courses as "a 'mass production' and 'rote-memorization' type of educational experience." Adams et al. (1994) concluded that presenting accounting as an interesting and vital profession might be an effective retention strategy for high-aptitude students. Effective use of the WSJ in the classroom is one way to enlighten, recruit and retain accounting students.

While this paper suggests use of WSJ, there are other suitable business publications, such as Business Week, Barron's, and Investor's Business Daily. The Wall Street Journal is emphasized for several reasons. First, the Wall Street Journal is a daily publication rather than a weekly periodical, as are Business Week and Barron's. As a result, the WSJ allows for a stream of on-going discussion throughout the semester on a chosen topic. For example, the recovery of businesses in New Orleans after Hurricane Katrina has been a hot topic throughout the past year. While Business Week and Barron's have produced excellent cover stories on the recovery of New Orleans, they do not deliver the frequency and depth of coverage of the WSJ. Second, while the Investor's Daily is an excellent newspaper, the Wall Street Journal is arguably more comprehensive in its coverage of myriad business-related issues. Finally, because the WSJ offers an expansive range of articles across different business disciplines, AIS students can broaden their understanding of how current events affect AIS, and link various topics together to gain an extensive view of the business world. 


\section{WHY USE THE WALL STREET JOURNAL?}

A fair question to ask would be, "How can I invest the time in reading the WSJ when I am already stretched thin with teaching, research, and service requirements?" The WSJ recognizes the time constraints of professors and provides resources. The WSJ Education program offers many tools to support usage of its paper in our classes. One great tool that the Journal offers educators is 'Weekly Reviews', which are written for 15 different disciplines, including: accounting, business ethics, business law, economics (macro and micro), entrepreneurship, finance, health care, business \& policy, hotel restaurant travel management, information technology, international business, introduction to business, journalism \& media, management, marketing, and political science. Each review is sent to university professors who are subscribers as an email on Friday mornings. Reviews include summaries of each article, a listing of topics covered, and several questions related to each article. The reviews serve well as a teacher's guide for class discussion. The review's questions can be adapted to suit your class and teaching style.

Students may resist inclusion of the WSJ as a mandated part of classroom materials. With the rising cost of textbooks and tuition, a subscription to the WSJ is an additional financial burden to students. Also, students might believe that the additional reading work will not be worth their time and money. If these are concerns, here are a few points to consider. First, is your school is an Academic Partner of the WSJ and/or are other professors at already requiring purchase of the WSJ? If so, your required use will not cost your students an additional fee. Else, should your students not be current subscribers, the WSJ is heavily discounted for students. ${ }^{1}$ When you introduce the WSJ to your students, I recommend spending some time in the first class addressing the above concerns and making the case for why the WSJ is an investment that is critical to their future success.

${ }^{1}$ A 15 -week student subscription to the Wall Street Journal for the spring semester 2008 cost just $\$ 29.95$ for home delivery and on-line access for the Monday-Saturday issues.

The primary way one can use the WSJ in AIS classes is to use articles to provoke class discussions on relevant topics. For instance, students can be assigned a WSJ article and given a list of questions to answer. These questions would ask them to analyze the underlying issues raised in the article and require them to do some additional research on the internet. Another creative way to integrate the WSJ into AIS classes might include having students develop a binder of WSJ article clippings on the topics covered during the course. Students would provide a one paragraph summary of how each article ties into the discussion during the week's class. I have observed that offering extra credit points for these article clipping has motivated students to read the WSJ. Once they have regularly read the WSJ, they often begin to see that it is a great resource for understanding accounting in the realworld. While using the WSJ in AIS classes might seem unusual, I next present some illustrative ways, both general and targeted, in which the WSJ can be used to reinforce topical areas and conceptual issues.

\section{REAL-LIFE APPLICATIONS}

In 2002, Pepsi Bottling Group, Inc.'s antiquated ordering system and the lack of instant data in the field was delaying smooth deliveries of Pepsi products, leaving retailers' store shelves empty. Pepsi Bottling was forced to implement a new program, which included technology upgrades, revised work schedules and renewed focus on customer service. To improve the accuracy of assembling orders in the warehouse, the company outfitted warehouse workers with bar-code scanners and headsets to reduce errors and eliminate paperwork. A computer program sorted through daily orders and generated an electronic voice instructing workers which drinks to load by hand or with a forklift. A worker affixed a printout with a bar code to each pallet. This new technology system reduced "out of stocks," improved accuracy of orders, and allowed more time to load delivery trucks (Terhune, 2006).

Not all new computer systems immediately improve the efficiency and accuracy of processing a company's product. In mid-July 1999 Hershey Foods Corp. flipped the switch on a \$112 million computer system that was supposed to automate and modernize everything from taking candy orders to putting pallets on trucks. The project called for 5,000 personal computers, as well as network hubs and servers and several different vendors. The system served Hershey's 1,200-person sales force and other departments for every step in the process, from original 
placement of an order to final delivery. It also ran the company's fundamental accounting and touched nearly every operation; tracking new ingredients; scheduling production; measuring the effectiveness of promotional campaigns; and setting prices. There was just one problem. The system failed to fill orders even as inventory grew for Hershey's busiest time-Halloween and Christmas. Great North Foods' order of 20,000 pounds of candy was delayed so that 100 of the 700 stores it supplies did not receive their candy orders. This snafu in the new system forced Hershey to ship delayed orders by air freight, rather than the typical and much less costly trucks. Not only did the new system cost Hershey candy sales, but it also strained relationships with its customers (Nelson \& Ramstad, 1999).

\section{MANAGERIAL DECISIONS}

While it is important to understand accounting technologies, principles, rules, processes and so on, such knowledge does not operate in a vacuum. Accounting students should also understand how accounting information can affect decision making and vice versa. For example, when assessing whether or not to close a factory plant, what accounting information might managers need to make such a critical decision and how do they obtain such information from their information systems? Is it possible that limited scopes and availabilities of accounting information could affect a decision of this nature in unexpected ways? Were there other alternatives that in hindsight might have been a better choice for the organization?

In recent years, outsourcing of jobs overseas has been a hot topic. While some companies have shipped jobs overseas to take advantage of labor cost savings, information systems at Viking Range Corp. have been used to keep jobs in Mississippi. Every stove and other major appliance made in Greenwood, Mississippi is made to order, which means the factory does not produce the item unless there is a customer. This system allows Viking to operate without a warehouse of finished appliances, which cuts its costs, while giving it the leeway to respond quickly to special orders for unusual models, such as a burgundy-colored six-burner range. Viking has addressed the outsourcing decision by proactively pursuing a strategy and information system that focuses on cutting costs and making smart decisions as to its production schedules (Aeppel, 2006).

\section{BUSINESS ETHICS}

With all the coverage in the press of the various corporate and accounting scandals, the WSJ provides excellent current case studies of firms that made unethical decisions and paid the price for these decisions. The fall of WorldCom illustrates how information systems were used unethically to perpetrate fraud. A series of events in the spring of 2002 led Cynthia Cooper, WorldCom's vice president of internal audit, and Gene Morse, a WorldCom internal auditor, to suspect that their employer was cooking its books. Ms. Cooper and her internal audit team set out to figure out whether their hunch was correct. Often working late at night to avoid detection by their bosses, they processed hundreds of thousands of accounting entries. They discovered that Scott Sullivan, chief financial officer of WorldCom, had been instructing the accountants to take line costs out of operating-expense accounts where they belonged and to record them as capital expenditures. This improper accounting treatment meant that the costs did not hit the company's bottom line immediately, but rather through depreciation entries over a long period of time. By June 23, 2002, Cooper's team unearthed $\$ 3.8$ billion in misallocated expenses and phony accounting entries. This added up to the largest accounting fraud in corporate history. The discoveries sent WorldCom into bankruptcy, left thousands of their colleagues without jobs and shocked the stock market (Pulliam \& Solomon, 2002). This scandal and others led to a renewed emphasis on internal controls, specifically accounting information systems to regain investors' confidence in the integrity of companies' accounting information systems.

\section{INTEGRATING WSJ INTO AIS COURSES}

Within AIS four areas have been identified that could be fruitful for class discussion. The following sections give examples of WSJ articles to use within these four areas. 


\section{INFORMATION PRIVACY}

Amid heightened privacy concerns, a handful of technology companies are touting new services designed to make existing email programs, such as Microsoft Corp.'s Outlook, more secure, with features ranging from email that cannot be forwarded to self-destructing messages that can be viewed only for a limited time. While most email programs guard against inbound attacks such as viruses and spam, they give computer users little control over messages that are sent. Hence, third-party developers, who are not working directly with Microsoft or other email companies, aim to fill privacy holes (Lavallee, 2006a). For example, RPost International Ltd. offers a product called Registered E-Mail ${ }^{\circledR}$ that alerts the sender when an email was delivered and opened, and can verify whether the content of the original message was changed (www.rpost.com). Another service provided by Echoworx Corp. called Secure Mail encrypts email so that messages cannot be read by anyone other than the intended recipient, as recipients must use a password or answer a predetermined question to open the email (www.echoworx.com). CDS Technologies LLC offer a product called Kablooey Mail which allows users to send messages that "self-destruct" after a set period of time, from 10 seconds to two weeks, so recipients can no longer access the content on the website (www.kablooeymail.com). Senders can track when an email was opened and how long a recipient viewed the message (Lavallee, 2006a).

In the wake of AOL's recent leak of search queries from 650,000 customers, a new service has launched that says it masks computer users' online activities. Many anonymization tools are aimed at helping users to avoid being tracked as they surf from one Web site to another. This new service from Relakks takes a more comprehensive approach (www.relakks.com). The service and the company behind it are based in Sweden, where backers say stiff privacy laws make it more difficult for law-enforcement authorities and others to gain access to private customer information. Subscribers use their existing Internet connections to access Relakks's encrypted network. Once connected, any Internet traffic, including email, Web browsing and online file sharing, is routed through the company's computers in Sweden. The user's local Internet service provider would see only the connection to Relakks, and wouldn't have any record of the user's online activities beyond that. Relakks is designed so that even if it were forced to open up its records, it would have little personal information on hand to turn over. The company said it doesn't retain any information about what its users do online (Lavallee, 2006b).

\section{DATA SECURITY}

The WSJ is rife with articles on data security. One such article entitled "Lockdown: Banks Make Online Services More Secure" (Vara, 2006) discusses how several major banks are attempting to make data more secure on their websites. Bank of America Corp., lets customers pick personal questions to be asked when they log in from a computer they haven't registered with the bank. ING Group NV now lets a customer choose an image, say, a basket of oranges from a menu of pictures, to personalize his or her log-in page. This feature makes it tougher for phishing schemes in which hackers create a fake bank home page and elicit personal information. Banks are taking data security more seriously because of consumer worries over online fraud. More than $5 \%$ of internet users say they have stopped banking online because of security concerns, up from less than $1 \%$ a year ago (Vara, 2006).

Another article useful for class discussion would be the rising use of web applications by hackers. In a report by security-software maker Symantec Corp, hackers have stepped-up their assault on home-computer users and financial services companies. Internet attackers are increasingly using Web browsers to infiltrate home computers, where they hope to gather sensitive consumer data (e.g. credit card numbers, bank information). In targeting consumer, hackers relied on email for many years. Because hackers have been able to successfully find and exploit large numbers of flaws in browsers and other widely used Web tools, the Web has been gaining ground as the hackers' approach of obtaining information for consumers. Hackers use such programming flaws to deposit malicious programs, such as bots and keystroke loggers, onto the computers of unwitting Web surfers. They do this by breaking into Web sites and planting malicious programs there or by setting up their own attack-laced sites and luring visitors to them, often through email invitations (Richmond, 2006). 


\section{IDENTITY THEFT}

The discussion of identity theft usually wakes up any sleepy student. I recommend selecting articles that discuss how identity thieves typically work and what is being done to stop them. Recent investigations of online identity-theft rings show a disturbing pattern emerging, law-enforcement officials say. Large groups of criminals are banding together to steal financial data from individuals, and then trade or sell that data on underground Internet sites. The Shadowcrew web-site case in New Jersey illustrates how criminal groups profit from stolen data. The indictment alleges that Shadowcrew members traded stolen personal data on a Web site called www.shadowcrew.com. Using online nicknames such as "Dirty Harry" and "NotoriousCarder," they bought and sold credit- and debit-card information, counterfeit drivers' licenses, passports and Social Security cards, the indictment alleges (Bryan-Low, 2005). This article explains in detail how Shadowcrew allegedly operated a secret web site that traded stolen credit and debit card information.

While identity theft is most often associated with the internet, a 2006 survey by Javelin Strategy \& Research revealed that lost or stolen wallets, checkbooks and credit cards account for the bulk of identity fraud. The survey revealed that data was stolen in following manner: lost of stolen wallets, checkbooks and credit cards $30 \%$, by someone you know $15 \%$, corrupt business employee $15 \%$, stolen mail or fraudulent change of address $8 \%$, offline financial transaction $7 \%$, data breaches $6 \%$, computer viruses, spyware or hackers $5 \%$, phishing $3 \%$, garbage $1 \%$, online financial transactions $0.3 \%$, and some other way $7 \%$ (Cullen, 2006).

With rising health care costs, some identity thieves have turned to stealing medical ID information. Your name and information such as your Social Security number and insurance coverage are used to obtain medical services or goods and, in some cases, money, by filing bogus claims. In many cases, medical ID thieves use your information to get medical treatment they need; they may change your billing address and phone number so you don't see the bills. Some organized crime rings will use the stolen IDs to obtain drugs -- like painkillers -- and then sell them on the street. In another case, a psychiatrist entered false diagnoses on the charts of individuals who weren't his patients and used their information to submit bills to an insurance company (Bernard, 2006). This form of thievery may be harmful to your health as well as your finances. If your medical records reflect another patient's ills, you could be incorrectly treated or denied treatment altogether.

\section{BACKUP RECOVERY}

With the advent of $9 / 11$ businesses understand the importance of backup and recovery of data. Shortly after 9/11, the WSJ ran a piece (Berman \& Coleman, 2001) on how companies struggled with the recovery of data. This article could be used to discuss different ways businesses backup data and how they implement disaster recovery plans. Another WSJ article by Bartley (2001) discussed how the Wall Street Journal was able to put out their newspaper the day after 9/11. This touching account of how courageous New Yorkers rose to the task of putting out a major newspaper the next day is a good example of superior planning and a sound disaster recovery plan in action.

\section{IMPLEMENTATION GUIDANCE}

Recent literature has indicated that today's generation of students seems to have a low threshold for boredom, as they thrive on action (Haywood et al. 2004). Students born after 1980 ("Generation Y" or "Nexters") believe that they are entitled to an education and that their learning is all up to the teacher (Faust et al. 2001). While I do not think that a student's learning is all up to the instructor, I do believe that we can design our courses to involve students in the process of active learning.

Research in educational psychology indicates that students learn and retain more of what they learn when they actively participate in problems rather than just listening to lectures (Eble, 1982; Pascarella \& Terenzini, 1991). Analyzing and discussing relevant WSJ articles in class provide students and instructors an opportunity to grapple with accounting issues. Accounting students need to be challenged to use critical-thinking skills to see a situation from the viewpoint of all interested parties (Haywood et al. 2004). This paper suggests that using the WSJ to discuss 
real-life applications of accounting information system not only improve student's understanding of AIS but also encourage them to be more actively involved in the learning process.

You may ask, "How do can I specifically integrate the WSJ into the grading scheme of my AIS class?" Based on my experience, I recommend that you assign and to discuss at least three WSJ articles during the semester, and suggest assigning a percentage of the students' overall course grade to these articles. Foran and Olds (2002) suggest that peer pressure, general interest in the subject matter, and the possibility of being called on in class should motivate students to complete their assignments. Unless there is some form of accountability (e.g. written assignment, quiz, exam, or class participation points), students likely will not read assigned articles. This is consistent with agency theory in which the agent (i.e. student) will be effort-averse in trying to getting as good as grade as possible with the least amount of effort. Thus, questions ought to be assigned for each WSJ article. Assignments can be graded on completeness and effort. Because many of the questions are open-ended there will not necessarily be a right or wrong answer. This allows the instructor to focus on the class discussion without spending inordinate time grading their assignments.

While one could use the WSJ's "Educators' Review" questions for some articles assigned, one could also write his or her own questions. I suggest trying to address most of the following levels of learning: knowledge, comprehension, application, analysis, synthesis, and evaluation. Some questions require only recall of the information offered in the article to see if students read and understood it. Other questions reach to higher level of learning, asking the student for the reasons behind the information offered in the article. Finally, I suggest writing questions that push beyond the article and ask students to apply the information - lessons learned, ripple effects of the event described in the article. The range of questions helps train students to think beyond just the facts of the article. As a result, the article can become a mini-case study.

\section{STUDENT RESPONSES TO READING WSJ}

As part of a student opinion survey administered by the author, students were allowed to provide written comments on the strengths and weaknesses of their class. Their responses of the use of the WSJ were overwhelming positive. Students mentioned that the WSJ class discussions were what they most enjoyed about the class. Also, they mentioned that the on-going discussions of issues in the WSJ allowed them to learn and respect other classmates' views and opinions.

\section{CONCLUSION}

Given the volume, depth and breadth of material we must cover with our students to prepare them for the CPA exam and their careers, should we fit the reading of the WSJ into the accounting curriculum in general and AIS courses in particular? Having successfully integrated the WSJ into accounting courses, this paper suggests that professors should regularly expose students to real-life applications of what we teach in the classroom. They need to understand the decision process of managers and how their decisions affect different stakeholder groups. Students need to grapple with issues they will face in the workplace including ethical dilemmas. When they interview for jobs, we desire them to be knowledgeable and articulate about the issues of the day. This paper suggests that the WSJ can provide students with a foundation for understanding and applying their technical knowledge to the real world of business.

\section{REFERENCES}

1. Adams, J. A., Pryor, L. J., \& Adams, S. L. (1994). Attraction and retention of high-aptitude students in accounting: An exploratory study. Issues in Accounting Education, 9(1), 45-58.

2. Aeppel, T. (2006). Still Made in the U.S.A.: Home of the Range; On the Mississippi Delta, Three Factories Churn out Iconic Viking Line. The Wall Street Journal, (October 25), B1.

3. Bartley, R. L. (2001). Thinking Things Over: One Newspaper's Catastrophe Recovery. The Wall Street Journal, (October 8), A27. 
4. Berman, D. K. \& Coleman, C. (2001). Companies Test System-Backup Plans as They Struggle to Recover Lost Data. The Wall Street Journal, (September 13), B5.

5. Bernard, T. S. (2006). Avoid Medical ID Theft. The Wall Street Journal, (July 30).

6. Bryan-Low, C. (2005). Identity Thieves Organize; Investigators See New Pattern: Criminals Team Up to Sell Stolen Data over the Internet. The Wall Street Journal, (April 2005), B1.

7. Cullen, T. (2006). How Thieves Access your Identity. The Wall Street Journal, (September 19), B1.

8. Eble, K. (1983). The Aims of College Teaching. San Francisco, CA: Jossey-Bass.

9. Faust, J., Ginno, E. A., Laherty, J., \& Manuel, K. (2001). Teaching information literacy to generation y: Tested strategies for reaching the headphone-wearing, itchy mouse-fingered and frequently paged. Poster Session, ACRL 10 ${ }^{\text {th }}$ National Conference, Denver, CO, March 15-18.

10. Foran, M. F. \& Olds, P. R. (2002). Using the Wall Street Journal and the Internet to Implement The AECC's Introductory Accounting Recommendations. Advances in Accounting Education, 4, 21-39.

11. Haywood, M. E., D. A. McMullen, \& D. E. Wygal. (2004). Using Games to Enhance Student Understanding of Professional and Ethical Responsibilities. Issues in Accounting Education, 19(1), 85-99.

12. Inman, B.C., Wenzler, A., \& Wickert, P. D. (1989). Square Pegs in Round Holes: Are Accounting Students Well-Suited to Today's Accounting Profession? Issues in Accounting Education, (Spring), 29-47.

13. Lavallee, A. (2006a). This Email will Self-Destruct New Services Help Safeguard Outbound Messages against Forwarding and Tampering. The Wall Street Journal, (August 31), D1.

14. Lavallee, A. (2006b). Service Aims to Cloak Internet Use by Routing Traffic through Sweden. The Wall Street Journal, (August 24), A10.

15. Nelson, E. and Ramstad, E. (1999). Trick or Treat: Hershey’s Biggest Dud Has Turned out to be its New Technology — at the Worst Possible Time, It Can't Fill its Orders, even as Inventory Grows-Kisses in the Air for Kmart. The Wall Street Journal, (October 29), A1.

16. Pascarella, E., and Terenzini, P. (1991). How College Affects Students. San Francisco, CA: Jossey-Bass.

17. Pulliam, S and D. Solomon. (2002). Uncooking the Books: How Three Unlikely Sleuths Discovered Fraud at WorldCom --- Company's Own Employees Sniffed Out Cryptic Clues And Followed Hunches --- Ms. Cooper Says No to Her Boss. The Wall Street Journal, (October 30), A1.

18. Richmond, R. (2006). Hackers' Use of Web Applications in Attacks Rises. The Wall Street Journal, (September 25), B5.

19. Terhune, C. (2006). Pepsi's Supply-Chain Fix: Bottler's Move to Modernize Delivery Yields Efficiency Benefits. The Wall Street Journal, (June 6), B3.

20. Vara, V. (2006). Lockdown: Banks Make Online Services More Secure. The Wall Street Journal, (August 23), D1. 
NOTES 